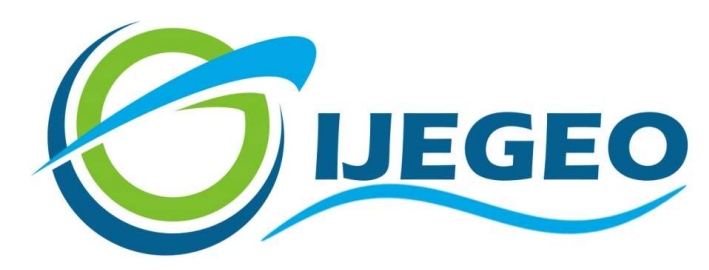

International Journal of Environment and Geoinformatics (IJEGEO) is an international, multidisciplinary, peer reviewed, open access journal.

\title{
First record of a-sexual reproduction by fission in Holothuria (lessonothuria) verrucosa (Selenka, 1867) from coastal waters of Karachi, Pakistan
}

\section{Quratulan Ahmed, Qadeer Mohammad Ali, Nurzafirah Mazlan and Levent Bat}

\author{
Editors \\ Prof. Dr. Cem Gazioğlu, Prof. Dr. Dursun Zafer Şeker, Prof. Dr. Ayşegül Tanık, \\ Prof. Dr. Şinasi Kaya, Assist. Prof. Dr. Volkan Demir
}

Scientific Committee (2018)

Assist. Prof. Dr. Abdullah Aksu, Prof. Dr. Bedri Alpar, Prof. Dr. Gülşen Altuğ, Prof. Dr. Lale Balas, Prof. Dr. Can Balas, Prof. Dr. Levent Bat, Prof. Dr. Bülent Bayram, Prof. Dr. Nuray Çağlar, Prof. Dr. Jadunandan Dash, Prof. Dr. A. Evren Erginal, Assoc. Prof. Dr. Ali Ertürk, Dr. Dieter Fritsch, Dr. Amin Gharehbaghi, Prof. Dr. Melike Gürel, Assoc. Prof. Dr. Tolga Görüm, Dr. Hakan Kaya, Prof. Dr. Fatmagül Kılıç, Assoc. Prof. Dr. Maged Marghany, Prof. Dr. Nebiye Musaoğlu, Prof. Dr. Masafumi Nakagawa, Prof. Dr. Haluk Özener, Prof. Dr. Erol Sarı, Prof. Dr. Elif Sertel, Prof. Dr. Nüket Sivri, Assoc. Prof. Dr. Füsun Balık Şanlı, Prof. Dr. Uğur Şanlı, Assoc. Prof. Dr. Hasan Özdemir, Prof. Dr. Taşkın Kavzoğlu Assoc. Prof. Dr. Oral Yağcı, Dr. Soofia Tahira Elias Özkan, Prof. Dr. Seyfettin Taş, Assist. Prof. Dr. Ömer Suat Taşkın, Dr. İnese Varna, Assoc. Prof. Dr. İ. Noyan Yılmaz, Assist. Prof. Dr. Baki Yokeş, Assit. Prof. Dr. Sibel Zeki 


\title{
First record of a-sexual reproduction by fission in Holothuria (lessonothuria) verrucosa (Selenka, 1867) from coastal waters of Karachi, Pakistan
}

\author{
Quratulan Ahmed ${ }^{1, *}$, Qadeer Mohammad Ali ${ }^{1}$, Nurzafirah Mazlan² and Levent Bat ${ }^{3}$ \\ ${ }^{1}$ Marine Reference Collection and Resources Centre, University of Karachi, Karachi, 75270, Pakistan. \\ ${ }^{2}$ Department of Diagnostic and Health Science, Faculty of Health and Life Sciences, Management and Science University, \\ Seksyen 13, Shah Alam, 25200 Selangor, Malaysia. \\ ${ }^{3}$ Sinop University Fisheries Faculty, Department of Hydrobiology, TR57000 Sinop, Turkey
}

Corresponding author*

Tel : +922199261645

E-mail : quratulanahmed_ku@yahoo.com
Received 15 Nov 2017

Accepted 01 March 2018

\begin{abstract}
An experiment of a-sexual reproduction by fission was conducted on sea cucumber, Holothuria (Lessonothuria) verrucosa (Selenka, 1867) for 98 days. Anterior fission was observed on Day 1 with the formation of fission on the body of the sea cucumber. Initial length of $14 \mathrm{~cm}$ and weight of $21 \mathrm{~g}$ was measured at Day 1 in an aquarium under laboratory condition. Complete fission was observed on Day 7 of experiment by formation of 2 specimens; $\mathrm{A}$ and P. Initial length and weight for A was $4.5 \mathrm{~cm}$ and $3.18 \mathrm{~g}$, while $\mathrm{P}$ was $9.5 \mathrm{~cm}$ and $17.30 \mathrm{~g}$ respectively. Increased weight for specimen A was observed on Day 20 with the first observation of the formation of anal pore. Tentacles started to form on specimen P on Day 34. Complete formation of anus on specimen A was seen on the 98th day of experiment with final weight of $3.84 \mathrm{~g}$ and length of $4.6 \mathrm{~cm}$. Large growth of tentacle was also seen on Day 98 of the experiment with a final weight of the specimen $P$ as $17.56 \mathrm{~g}$ and length as $9.7 \mathrm{~cm}$.
\end{abstract}

Keywords: Asexual reproduction, fission, Holothuria verrucosa, Pakistan

\section{Introduction}

A total of 19 species of sea cucumbers belonging to the class Holothuroidea are reported from Pakistan. Eight of them belong to the family Holothuriidae, 3 to the family Cucumariidae, 2 to the family Synaptidae, 2 to the family Sclerodactylidae and 4 to the family Phyllophoridae. Taxonomic detail of Holothuria (Lessonothuria) verrucosa (Selenka 1867) from Karachi coast was published by Ahmed et al. (2016). However, no data are available on the a-sexual and sexual reproduction of holothurians from Pakistan coasts.

The objective of the present study was to establish the information regarding a-sexual reproduction of sea cucumber under laboratory conditions. This study will provide information related to the holothurians a-sexual reproduction under laboratory conditions in Pakistan.
Studies on the asexual reproduction of holothurians by fission are relatively scarce (Emson and Wilkie 1980; Lawrence 1987; Smiley et al. 1991; Mladenov and Burke 1994). Asexual reproduction through fission is a feature of many of the most abundant Aspidochirote holothuroids in the Indo-Pacific region (Uthicke 1997 and 2001). Fissiparous species split in half and the two halves regenerate to make complete individuals. Thus far, six Holothuria and two Stichopus species are known to be fissiparous and asexual reproduction appears to be a major form of reproduction used in maintaining populations (Ebert 1978; Harriott 1982; Conand and de Ridder 1990; Chao et al. 1994; Conand et al. 1997; Uthicke 2001).

The aim of this study was to observe a-sexual reproduction in $H$. verrucosa by fission during November 2015 to April 2016 under laboratory conditions. 


\section{Materials and Methods}

A total of 71 sea cucumbers were collected from the Buleji (245ㅇ' $\left.20.41^{\prime \prime} \mathrm{N}, 66^{\circ} 49^{\prime} 24.15^{\prime \prime} \mathrm{E}\right)$ and Sunehri (245' $\left.33.49^{\prime \prime} \mathrm{N}, 66^{\circ} 40^{\prime} 40.20^{\prime \prime} \mathrm{E}\right)$ coast during November 2015 to April 2016. Animals were brought to the laboratory by keeping them in polythene bag filled with sea water and supplied with aeration. The area of study was shown on the map in Figure 1. A-sexual reproduction was observed in one of the $\mathrm{H}$. verrucosa collected from Buleji coast on 25th of November 2015 , with a tide of $-0.30 \mathrm{~m}$ from intertidal area on rocky shores under hard rock. The initial length and weight of the animal was recorded. The physicochemical parameters such as water temperature $\left({ }^{\circ} \mathrm{C}\right)$, salinity and $\mathrm{pH}$ were measured by multi-parameters. For morphological and a-sexual reproduction characteristics, length $(\mathrm{cm})$ and weight $(\mathrm{g})$ were examined in laboratory on daily basis. Animal was externally examined for signs of fission, changes in physiology and anatomy were noted, and its movement was observed as well. Water salinity was maintained every 15 days by adding a $25 \%$ of fresh sea water into the aquarium. Experiment was conducted for 98 days. Microphotography was also performed using a digital camera (Fujifilm 16 MP).

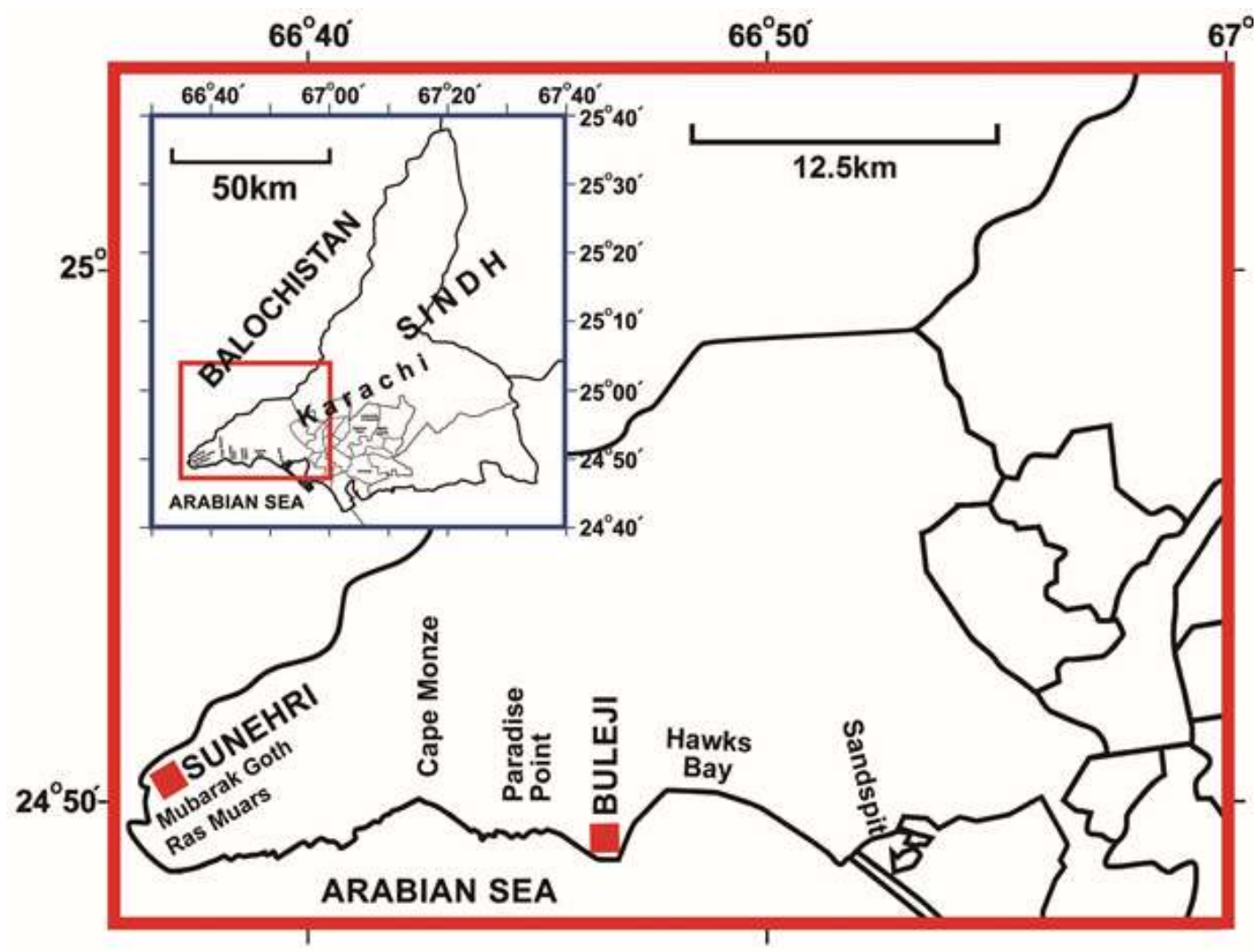

Fig 1. Study area map of Sunehri and Buleji coast

\section{Results}

During routine surveys of holothurians on Buleji coast on 25th November 2015 a specimen of $H$. verrucosa was observed to constrict slightly from anterior (Fig.2A) and it was collected carefully and transported to a laboratory aquarium with running seawater for observation.
Table 1 shows physico-chemical parameters of the study area on Buleji coast recorded on 25th November 2015 when the animal was collected. Table 2 shows maintained hydrological parameters in the aquarium throughout the experiment. 
Water temperature was $30.60 \pm 0.82^{\circ} \mathrm{C}$, salinity was $36.80 \pm 0.83(\%)$ and $\mathrm{pH}$ was $8.10 \pm 0.12$ in the aquarium during the experiments in April and February (Table 2). A-sexual characteristics by fission were observed in $H$. verrucosa collected from Buleji coast from the intertidal area on rocky shores under the hard rock. Anterior fission was observed on the body wall of $H$. verrucosa. Coloration of fresh specimens was burnt sienna and fission point was located on the anterior end of the specimen (Figure $2 \mathrm{~A}$ B). An initial length of $14 \mathrm{~cm}$ and weight of 21 $\mathrm{g}$ were measured at Day 1 of the experiment. On Day 2, animal was observed to be moving in anti-clock wise rotation. Animal was also seen twisting, turning, whirling and rotating which eventually led to formation of fission on the body wall (Figure 2C).

On Day 6, animal was continuously twisting on the opposite side direction and fission point was very clear, consequently a thin body wall between $\mathrm{A}$ and $\mathrm{P}$ developed and looked like a loop. A loop-like body wall was more stretched between the opposite sides (Figure 2 D). On Day 7, complete fission was achieved, and two animals were formed into specimen $\mathrm{A}$ and specimen $\mathrm{P}: \mathrm{A}=$ anterior specimen with an existing mouth at one end and a closed wound; $\mathrm{P}=\mathrm{a}$ posterior specimen with an anus at one end and a closed wound at the other. The length and weight of specimen A were $4.5 \mathrm{~cm}$ and $3.18 \mathrm{~g}$, respectively. Specimen $P$ had a length of $9.5 \mathrm{~cm}$ and a weight of $13.30 \mathrm{~g}$ (Figure $2 \mathrm{E}-\mathrm{G}$ ).

On Day 20, anal pore formation was observed in specimen $\mathrm{A}$, the measured length and weight were $4.5 \mathrm{~cm}$ and $2.04 \mathrm{~g}$, respectively. No obvious gross anatomical development was observed on specimen $\mathrm{P}$ but there was a slight weight increase to $13.46 \mathrm{~g}$. Both specimen A and $\mathrm{P}$ were in relaxed and active condition (Figure 2 I-J). On Day 29, the weight of specimens continued to increase to $2.95 \mathrm{~g}$ in specimen A and $13.84 \mathrm{~g}$ in specimen P. Small outgrowth of anus was observed in specimen A. Specimen A and $\mathrm{P}$ were seen in active and relaxed condition (Figure $2 \mathrm{~K}-\mathrm{L}$ ).

Formation of tentacle outgrowth was observed on specimen P on Day 34, and large anal pore formation with thin membrane was observed on specimen A on the same day (Figure $2 \mathrm{M}-\mathrm{N}$ ). On Day 41, tentacle growth formation was observed on specimen $\mathrm{P}$ and an anus pore covered with thick yellowish membrane was clearly observed on specimen A (Figure 3 A-C). Weight of specimen $\mathrm{P}$ showed a great increase from 13.84 $\mathrm{g}$ to $16.53 \mathrm{~g}$ on Day 29 , however, the length remained the same. Specimen A was more active than specimen P. On Day 48, the anus pore was seen covered with thick membrane on the inner side of the wall. Small tentacle formation was seen on specimen $\mathrm{P}$ (Figure $3 \mathrm{E}-\mathrm{F}$ ).

A tiny, peltate shaped tentacle was formed on the Day 82 of the experiment on specimen P (Figure 4 D-E). Complete formation of anal pore on specimen A was seen on Day 98 of experiment and the length and weight recorded were $4.6 \mathrm{~cm}$ and $3.84 \mathrm{~g}$, respectively. The tentacle formation was also clearly seen on specimen P on Day 98 with recorded length and weight as $9.7 \mathrm{~cm}$ and $17.56 \mathrm{~g}$, respectively. The specimens were also seen active on the last day of the experiment. The specimens were seen attached on the aquarium wall and base during the 98-days of the conducted experiment.

Table 1. Physico-chemical parameters on Buleji coast on 25th November 2015

\begin{tabular}{cccc}
\hline $\begin{array}{c}\text { Tide } \\
(\mathrm{m})\end{array}$ & $\begin{array}{c}\text { Water temperature } \\
\left({ }^{0} \mathrm{C}\right)\end{array}$ & $\mathrm{pH}$ & $\begin{array}{c}\text { Salinity } \\
(\%)\end{array}$ \\
\hline-0.30 & 26 & 8 & 38 \\
\hline
\end{tabular}




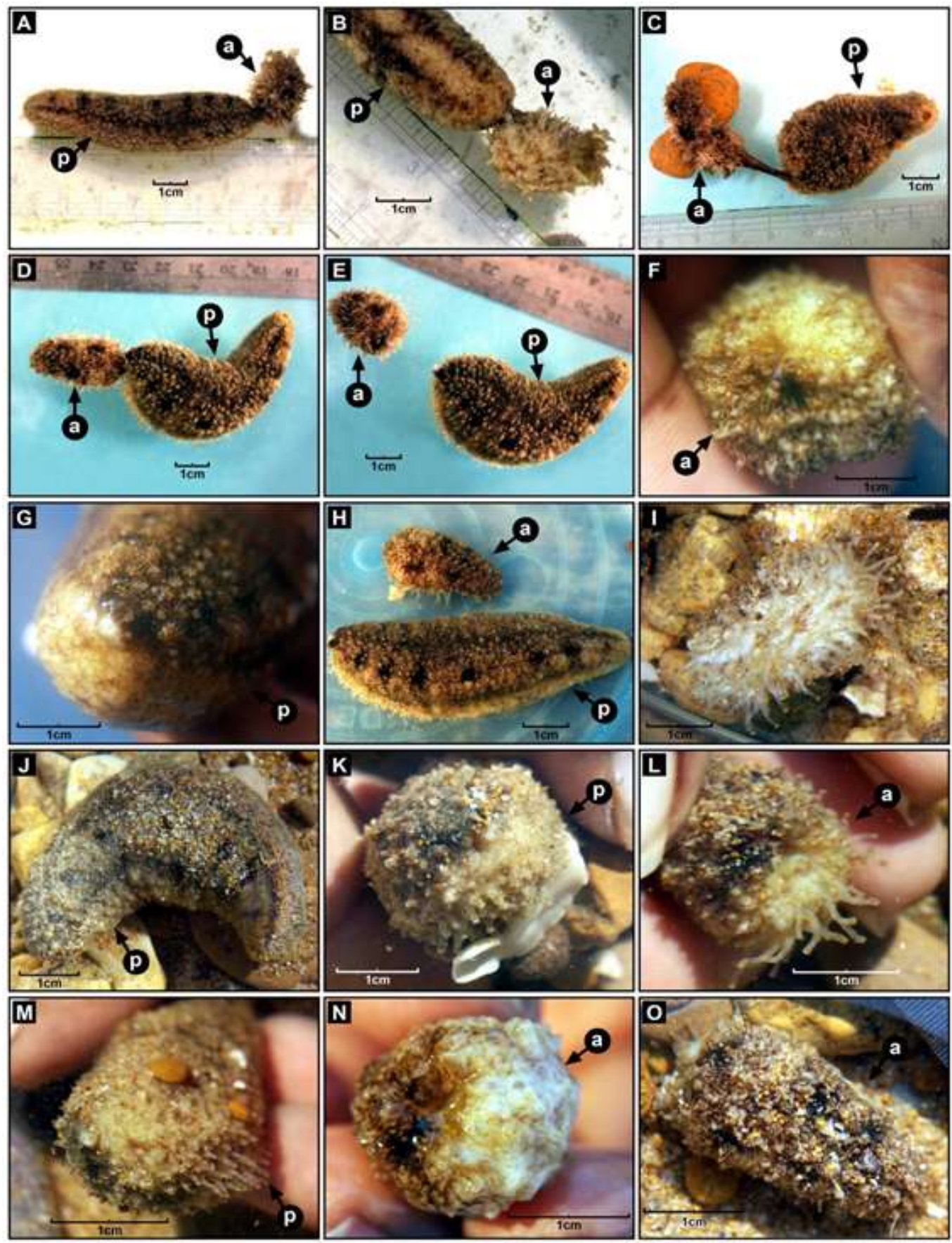

Fig 2. Holothuria verrucosa fission occurs from anterior side of the animal [A; Day 1 of xperiment, animal (dorsal), B; Day 1 of experiment, animal (Ventral), C; Day 2 (twisting), D; Day 6 twisting continue, E-G; Day 7, (fission completed with two separate specimen form) 'A' (anterior specimen with mouth and tentacles) and 'P (posterior specimen with anus), H; Day 7, A and P specimen in relax condition, I-J Day 20, specimen A (ventral) P (dorsal), K-L Day 29, small outgrowth for tentacles formation in specimen P and anal pore formation in specimen A, M-N; Day 34, tentacle outgrowth formation in specimen $\mathrm{P}$ and large anal pore formation with thin membrane was observed in specimen A. O; Day 38, dorsal view of specimen A in relaxes condition. 
Table 2. Physico-chemical parameters were maintained in aquarium during the experiment

\begin{tabular}{cccc}
\hline Months & $\begin{array}{c}\text { Water temperature } \\
\left({ }^{0} \mathrm{C}\right)\end{array}$ & $\begin{array}{c}\text { Salinity } \\
(\% 0)\end{array}$ & $\mathrm{pH}$ \\
& $\begin{array}{c}\text { Mean } \pm \text { SD } \\
(\text { Min-Max })\end{array}$ & $\begin{array}{c}\text { Mean } \pm \text { SD } \\
(\text { Min-Max })\end{array}$ & $\begin{array}{c}\text { Mean } \pm \text { SD } \\
(\text { Min-Max })\end{array}$ \\
\hline December & $29.10 \pm 0.89$ & $36.60 \pm 0.54$ & $8.04 \pm 0.89$ \\
& $(28.00-30.00)$ & $(36.00-37.00)$ & $(8.00-8.20)$ \\
January & $29.60 \pm 0.82$ & $36.60 \pm 0.89$ & $8.06 \pm 0.13$ \\
& $(28.50-30.50)$ & $(36.00-38.00)$ & $(8.00-8.30)$ \\
February & $29.70 \pm 0.44$ & $36.80 \pm 0.83$ & $8.10 \pm 0.12$ \\
& $(29.00-30.00)$ & $(36.00-38.00)$ & $(8.00-8.30)$ \\
March & $30.20 \pm 0.57$ & $36.40 \pm 0.89$ & $8.04 \pm 0.89$ \\
& $(20.50-31.00)$ & $(36.00-38.00)$ & $(8.00-8.20)$ \\
April & $30.60 \pm 0.82$ & $36.66 \pm 0.54$ & $8.06 \pm 0.13$ \\
& $(30.00-32.00)$ & $(36.00-37.00)$ & $(8.00-8.30)$ \\
\hline
\end{tabular}

\section{Discussion and Conclusion}

Dolmatov (2014) discussed asexual reproduction, features of fission, and regeneration of anterior and posterior fragments in holothurians in his review article. $\mathrm{He}$ described a-sexual reproduction in the larval stages and in adult holothurians by fission mechanism. Monticelli (1896) differentiated three fission mechanisms in $O$. planci by constriction, twisting, or stretching. In the present study, the specimen was divided into two specimens by the same process. Conand and Ridder (1990) observed a-sexual reproduction in Holothuria atra, the body divided into two fragments with an anterior: posterior length ratio of 4: 5 . In the present study the $H$. verrucosa divided into two specimens with a ratio of 1:2. Conand et al. (1997) observed asexual reproduction in $\mathrm{H}$. leucospilota, the length of the anterior fragments constitutes approximately $19 \%$ of the total body length. Jessica et al. (2008) observed asexual reproduction by fission in Holothuria hilla, the fission products of the specimen was 1:2. Asexual reproduction by fission in Holothuria atra was reported by Asha and Diwakar (2015). During the field surveys, the specimen was observed in twisting pattern moving in opposite direction and it constricted its mid body part throwing out internal organs, particularly the gonad, and eventually the body was separated into two halves. The process of asexual reproduction by transverse fission in Stichopus chloronotus observed in laboratory aquarium the specimen showed the posterior half of the individual remained stationary, while the anterior end continued to move forward this resulted in a more distinct constriction (Uthicke 2001). Present studies were indicated similar observation during the experiment. Fission is considered to play a significant role in maintaining populations of several holothuroids by compensating for mortality and migration (Ebert 1978; Harriott 1982; Chao et al. 1994; Uthicke 2001). This is the first description of the process of asexual reproduction in $H$. verrucosa. However, the observations are based on only one individual and experiment was carried out in aquarium conditions. 

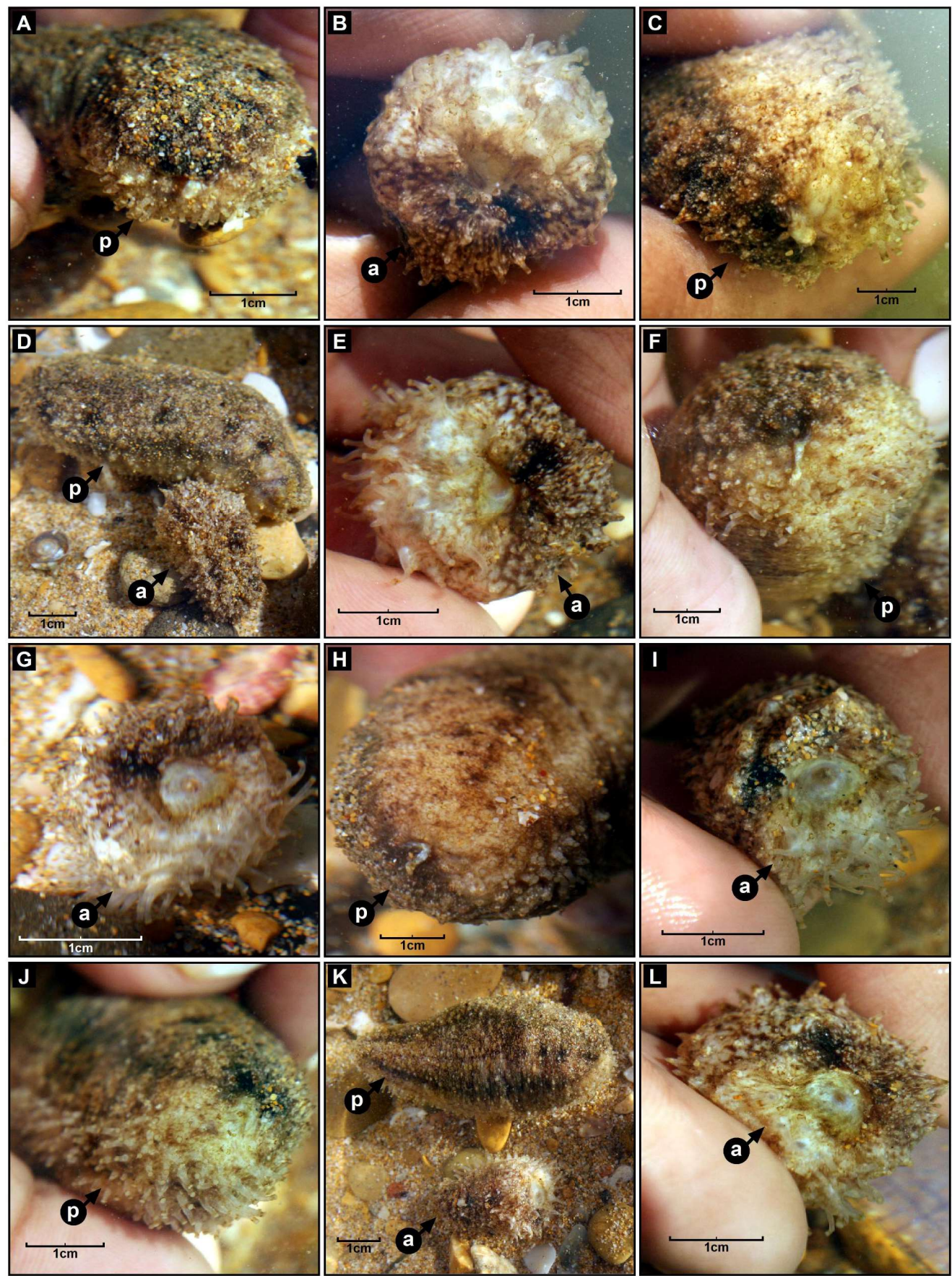

Fig 3. A-C; Day 4, tentacle formation in specimen $\mathrm{P}$ and anus formation in specimen A, D; specimen $\mathrm{A}$ and $\mathrm{P}$ in relax condition, E-F; Day 48, anus pore formed, inner side covered with thick membrane in specimen A and tentacle formation in progress, no tentacle observed on specimen P. G-H; Day 55 anus pore was observed clearly on specimen A but no tentacle observed on specimen P, I-J; Day 64, small outgrowth was observed outside on specimen A and tiny tentacles formation around the mouth of the specimen P, K; Specimen A and P in relax condition. L; outgrowth of anus in specimen A. 

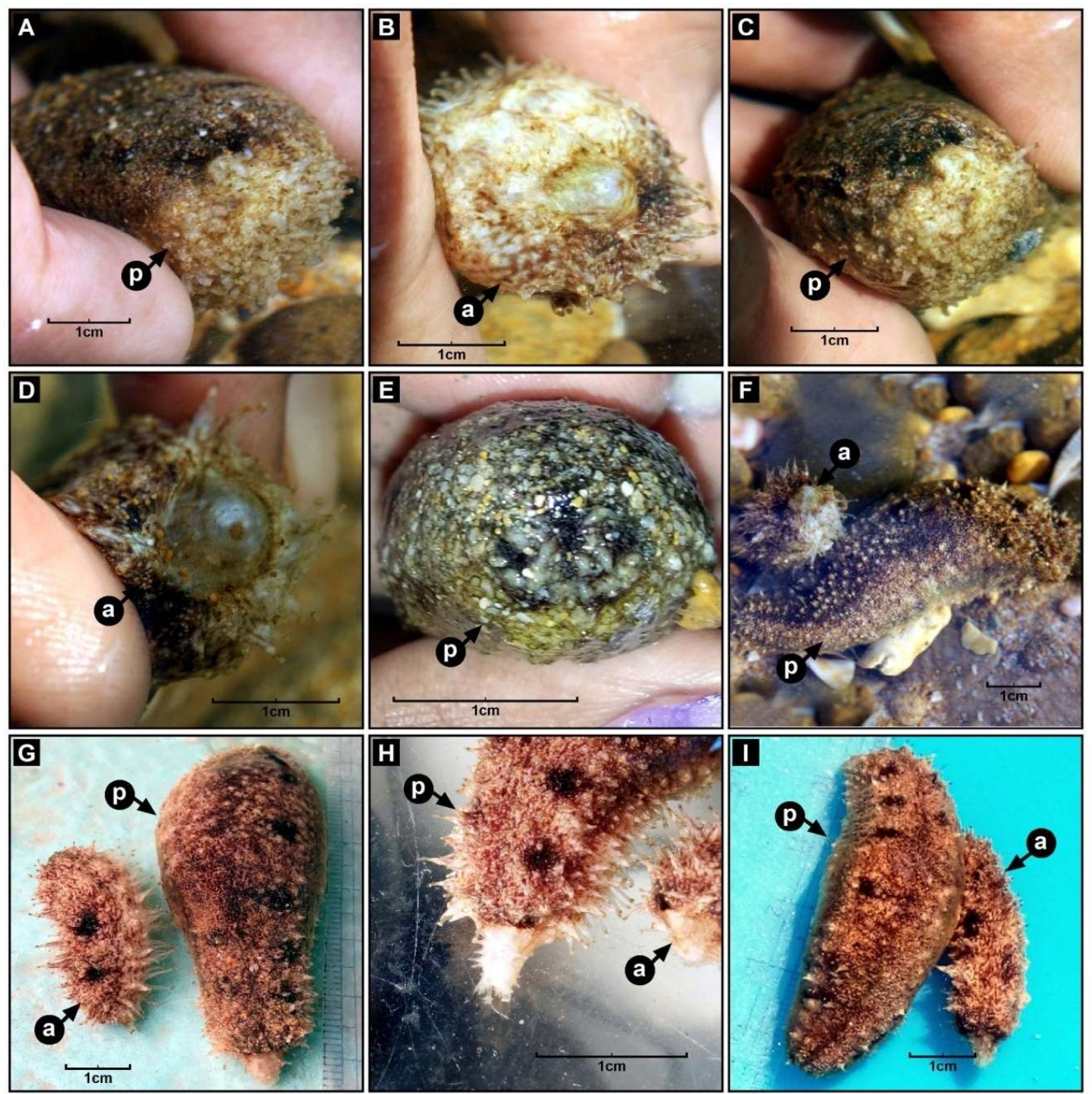

Fig 4. Day 71, A-C; Tentacle and anus formation were seen on specimen P and A, D-E; Day 82, anus outgrowth with clear anus pore and tiny peltate shape tentacle formation. F-G; Day 90, both specimen relaxed in aquarium, H-I; Day 98, tentacle formation with large outgrowth.

The present study is first description of the process of asexual reproduction in Holothuria (Lessonothuria) verrucosa (Selenka, 1867) from Karachi coastal waters of Arabian Sea. This study may provide useful data since no previous studies have been conducted on population density of holothurians from Pakistan coasts.

\section{Conflict of interest statement}

We declare that we have no conflict of interest.

\section{Acknowledgements}

The researchers wish to acknowledge the Higher Education Commission of Pakistan, (Grant No. IPFP/HRD/HEC/1688) which supported by financially for sample collection of holothurians and also to acknowledge the Marine Reference Collection and Resources Centre, University of Karachi for providing laboratory facilities during the study. 


\section{References}

Ahmed, Q., Ali, Q.M., Conand, C. 2016. New additions to the holothurian fauna of Pakistan: Holothuria verrucosa, Holothuria cinerascens and Ohshimella ehrenbergii, SPC Beche-de-mer Information Bulletin 36: 20-23.

Asha, P.S., Diwakar, K. 2015. Field observation of asexual reproduction by fission in sea cucumber Holothuria atra. Mar. Fish. Infor. Serv., T \& E Ser., No. 223 \& 224.

Chao, S.M., Chen, C.P., Alexander, P.S. 1994. Reproduction and growth of Holothuria atra (Echinodermata: Holothuroidea) at two contrasting sites in southern Taiwan. Marine Biology 119: 565570.

Conand, C., DeRidder, C. 1990. Reproduction asexuée par scission chez Holothuria atra (Holothuroidea) dans des populations de platiersrécifaux. p. 71-76. In: De Ridder, Dubois, LahayeetJangoux (eds). Echinoderm Research.Balkema, Rotterdam.

Conand, C. 1996. Asexual reproduction by fission in Holothuria atra. Variability of some parameters in populations from the tropical Indo-Pacific. Oceanol. Acta 19: 209-216.

Conand, C., Morel, C., Mussard, R. 1997. A new study of asexual reproduction in holothurians: Fission in Holothuria leucospilota populations on Reunion Island in the Indian Ocean. SPC Beche-de-Mer Information Bulletin 9: 5-11.

Dolmatov, I.Y. 2014. Asexual Reproduction in Holothurians. The Scientific World Journal,13 pages. http://dx.doi.org/10.1155/2014/527234.

Ebert, T.A. 1978. Growth and size of the tropical sea cucumber Holothuria (Halodeima) atra Jager at Enewetak Atoll, Marshall Islands. Pacific Science 32:183-191.
Emson, R.H., Wilkie, I.C. 1980. Fission and autotomy in echinoderms. Oceanography Marine Biology Ann. Rev. 18: 155-250.

Harriott, V. 1982. Sexual and asexual reproduction of Holothuria atra Jaeger at Heron Island Reef, Great Barrier Reef. Australian Museum Memoir 16: 53-66.

Lawrence, J.M. 1987. A functional biology of echinoderms.Croom Held ed, London, $340 \mathrm{p}$.

Mladenov, P., Burke, R. 1994. 9. Echinodermata: asexual propagation, in: Reproductive biology of invertebrates, K.G. and R.G. Adiyodi (eds.) Oxford Publishing 6: 339-383.

Monticelli, F.S. 1896. Sull' autotomia delle Cucumaria planci (Br.), Atti della Reale Accademia dei Lincei. Classe di Scienze Fisiche, Matematiche e Naturali. Rendiconti 5: 231-239.

Selenka, E. 1867. BeitragezurAnatomie und Systematik der Holothurien. Der Philosophischen Facultatzu Gottingen in December 1866, als Dissertation vorgelegt. 291-374.

Smiley, S., McEuen, F.S., Chaffee, C., Krishnan, S. 1991. Echinodermata: Holothuroidea, in: Reproduction of Marine lnvertebrates, Giese, A., Pearse, J.S. and Pearse, V.B. (eds.) Boxwood press, California 9: 663-749.

Uthicke, S. 1997. Seasonality of asexual reproduction in Holothuria (Halodeima) atra, H. (H.) edulis and Stichopus chloronotus (Holothuroidea: Aspidochirotida) on the Great Barrier Reef. Marine Biology 129: 435-441.

Uthicke, S. 2001. Influence of asexual reproduction on the structure and the dynamics of Holothuria (Halodeima) atra and Stichopus chloronotus populations of the Great Barrier Reef. Marine Freshwater Research 52: 205-215. 